Piśmiennictwo zakonne $w$ dobie staropolskiej, red. Magdalena Kuran, Katarzyna KaczorScheitler i Michał Kuran, przy współpracy Dawida Szymczaka, Łódź 2013.

RadosŁaw RusnaK ${ }^{1}$

Uniwersytet Warszawski

\title{
Uwagi na marginesie edycji bazyliańskiego poematu $O$ zabiciu Młodzianków
}

Piśmiennictwo wyrosłe ze środowisk klasztornych dawnej Rzeczypospolitej, nierzadko całe dziesięciolecia przechowywane w bibliotekach ukrytych przed wzrokiem postronnych, z całą pewnością należy do tej części rodzimego dziedzictwa, które wciąż jeszcze nie zostało w dostateczny sposób w refleksji naukowej wyeksploatowane, a w jego obrębie nadal liczyć można na tyleż frapujące dla każdego filologa, co nieoczekiwane odkrycia; jak w przypadku związanego z działalnością kresowych bazylianów religijnego poematu $O$ zabiciu Młodzianków. I chociaż spisany anonimową ręką utwór, podobnie jak mieszczący go rękopis z zasobów wrocławskiego Ossolineum², nieobcy jest literaturoznawstwu już od blisko stulecia ${ }^{3}$, dopiero obecnie szansę na dokładniejsze zaznajomienie się z tym niecodziennym zabytkiem zyskuje szersze grono odbiorców, a to dzięki edycji poematu, jaka ukazuje się w firmowanej przez Instytut Badań Literackich PAN serii Biblioteka Pisarzy Staropolskich ${ }^{4}$.

Doprowadzonego właśnie do szczęśliwego końca przedsięwzięcia wydawniczego nie czyniła wcale mniej absorbującym ani zawiła sytuacja tekstologiczna, z jaką mamy w tym przypadku do czynienia, ani nazbyt miejscami koślawa polszczyzna autora, ani wreszcie epicka bujność utworu, ujmującego nieczęsto przywoływany w beletrystyce temat rzezi betlejemskich niemowląt w szerokim kontekście odwiecznej walki dobra ze złem, samą zaś ofiarę składaną przez Młodzianków w kategoriach koniecznej antecedencji odkupieńczej męki Chrystusa. Kolejne oktawy ambitnie kleconego eposu z dużą sugestywnością stawiają przed oczy przerażające czeluście piekła i same

\footnotetext{
${ }^{1}$ Radosław Rusnak, (ur. 1978) adiunkt w Instytucie Literatury Polskiej Uniwersytetu Warszawskiego, autor monografii Seneca noster. Studium o dawnych przekładach tragedii Seneki Młodszego (Warszawa 2009), do jego zainteresowań naukowych należą związki literatury staropolskiej z antykiem i dawnymi literaturami romańskimi, translatoryka i dramat europejski wieku XVI.

${ }^{2}$ Unikatowy rękopis, podchodzący — jak należy przypuszczać — z bazyliańskiego klasztoru w Żyrowicach, oznaczony jest sygnaturą 4872/I, a jego szczegółowy bibliologiczny opis, wraz z próbą nakreślenia losów zabytku, zamieszcza w swojej monografii Julian Lewański — tenże, Polskie przekłady Jana Baptysty Marina, Wrocław 1974, s. 30-33.

${ }^{3}$ Za pierwszą odnoszącą się do omawianego tekstu literaturoznawczą wypowiedź uznać trzeba: A. Brückner, "Epopeja bazyliańska”. Nieznany okaz literatury rusko-polskiej, „Zapysky Naukowoho Towarzystwa im. Szewczenka”, R. 1913: Lwów 1914, s. 197-206.

${ }^{4}$ G. B. Marino-Anonim, O zabiciu Młodzianków, wydał R. Rusnak, Warszawa 2012, „Biblioteka Pisarzy Staropolskich", t. 41.
} 
wyżyny nieba, odstręczającą siedzibę Pomsty i skrytą w egipskiej głuszy jaskinię Snu, dręczonego śmiertelną trwogą Heroda i zdążającą ku bezpiecznemu Egiptowi Świętą Rodzinę, dla dwóch ostatnich części rezerwując właściwą deskrypcję masakry, którą zgodnie z logiką utworu dydaktycznego ${ }^{5}$, wieńczy rozpaczliwa ekspiacja okrutnego tyrana oraz triumfalna wizja zstępujących w męczeńskiej glorii do Limbo niemowlęcych dusz. Żyjącego u schyłku baroku mnicha ten osobliwy melanż solidnie zaaplikowanych dawek sensualizmu, makabry i religijnego uniesienia wyraźnie pociąga, a przy okazji motywuje do wytężonej, trwającej być może całe lata pracy, ale bynajmniej nie z uwagi na osiagnięty przez niego artystyczny efekt $O$ zabiciu Młodzianków doczekuje swojego spóźnionego pierwodruku. Istotny, oprócz niewątpliwie przyciągającej uwagę fabuły, okazał się fakt, iż bazylianin dokonuje przekładu La strage de gl' innocenti (Rzezi niewiniątek) Giambattisty Marina, zaświadczając tym samym silniejszy, niż mogłoby się wydawać, rezonans poetyki Neapolitańczyka w naszej części Europy.

Jeśli jednak dopuścić chcielibyśmy Anonima do grona rodzimych marinistów ${ }^{6}$, to raczej jako marinistę „wyrodnego", nie przyznającego się w żadnym miejscu do swych faktycznych inspiracji, zatracającego z dużą konsekwencją specyficzny, nieco przewrotny charakter tłumaczonego dzieła. Sama zresztą zawartość wzmiankowanego manuskryptu, a znalazły się w nim i rozmaite pieśni nabożne, i wierszowana historia o św. Teodorze Aleksandryjskiej, i wyjątek z traktatu o stopniach doskonałości, nie pozostawiają złudzeń, iż w redagowanej przez siebie z mozołem własnej wersji włoskiego poematu dostrzega bazylianin przede wszystkim płynący zeń pożytek duchowy, narzucający się z siłą tym większą, że za pośrednictwem sugestywnych, przyprawiających o trwogę i żałość obrazów. Ignorując werbalizowane w tekście oryginału nawiązania do sztuk plastycznych oraz implikowany nimi emulacyjny charakter dzieła, polski autor, choć niegłuchy przecież na konceptystyczną szatę Marinowej narracji, redukuje, czy też ujednoznacznia, i włącza, jak należy podejrzewać, do zestawu pobożnych lektur

\footnotetext{
${ }^{5}$ A jest to przy okazji również logika włoskiej tragedii krwawej okresu renesansu, do której za pośrednictwem swego pierwowzoru O zabiciu Młodzianków wyraźnie się odwołuje. By tej przerażającej i bezprecedensowej zbrodni nie pozostawić bez należytego zadośćuczynienia, Marino, a z nim Anonim, przedstawiają dotkniętego osobistym dramatem oprawcę, pogrążonego w rozpaczy i odwołującego zbyt pospiesznie wydany rozkaz. W podobny sposób ten sam Herod żałuje poniewczasie swej uprzedniej popędliwości w Mariannie (1565) Lodovico Dolcego, gdzie właściwą refleksję nad grozą popełnionych czynów przynosi dopiero zbyt późno uzyskany dowód faktycznej wierności zabitej żony. O innych powinowactwach Rzezi niewiniątek z konwencjami gatunku tragicznego zob. R. Rusnak, „Homo metaphoricus” jako morderca. Koncept w „Rzezi niewiniątek” Giambattisty Marina i w jej polskim ttumaczeniu, „Pamiętnik Literacki”, R. 95: 2004, z. 3, s. 77-78.

${ }^{6} \mathrm{~W}$ jednym rzędzie z Janem Andrzejem Morsztynem, Stanisławem Herakliuszem Lubomirskim i pozostałymi tłumaczami neapolitańskiego mistrza sytuuje bazylianina Julian Lewański $(d z$. cyt.). Najnowsza publikacja Biblioteki Pisarzy Staropolskich wpisać się zresztą pragnie w szerszy nurt badań nad polskim marinizmem, którego pokłosiem stały się m.in. rozprawy Marinellego i Nowickiej-Jeżowej oraz edycja XVII-wiecznej anonimowej translacji Adona - G. B. Marino, Adon, t. 1-2, oprac. L. Marinelli, K. Mrowcewicz, Roma-Warszawa 1993; L. Marinelli, Polski Adon. O poetyce i retoryce przektadu, Izabelin 1997; A. Nowicka-Jeżowa, Jan Andrzej Morsztyn i Giambattista Marino. Dialog poetów europejskiego baroku, Warszawa 2000.
} 
swoich współbraci utwór, w którym nam upatrywać wypada raczej manierystyczny z ducha, zaprawiony sporą dozą brutalizmu popis własnej poetyckiej sprawności Włocha, wynik eksplorowania przeciwległych względem Adona estetycznych jakości i przejaw nie do końca szczerej ekspiacji poety, podjętej w obliczu przedsiębranej z coraz większym zapałem kontrakcji hierarchów na demonstracyjną świeckość jego poème de paix?

Swoistość sporządzonej przez Anonima translacji, zwłaszcza w kontekście jej obcego pierwowzoru, uchwycić usiłowaliśmy w proponowanych swego czasu studiach ${ }^{8}$. Dziś rozważania te uzupełnić warto o garść spostrzeżeń będących pokłosiem filologicznego oglądu dochowanych przekazów źródłowych. Skłania do nich ponadto i ta szczęśliwa okoliczność, iż wzmiankowany rękopis z zasobów Ossolineum przechowuje aż trzy osobne redakcje poematu, nie wszystkie kompletne i niekoniecznie rozmieszczone w należytym porządku, rejestrujące wszakże w nieoceniony dla badacza sposób kolejne fazy kształtowania się tekstu, co pozwala wniknąć w tajniki translatorskiego warsztatu Anonima i ocenić drogi dochodzenia do scharakteryzowanej uprzednio postaci finalnej utworu. Tym samym wzięcie pod uwagę nie jednej, ostatecznej, lecz wszystkich udokumentowanych wersji $O$ zabiciu Młodzianków przydaje tłumaczeniu niejako trzeci wymiar, głębię umożliwiającą uchwycić go in statu nascendi, jako żywy, przeobrażający się na rozmaite sposoby pod wciąż nieusatysfakcjonowanym piórem organizm.

Zaznaczmy od razu, iż podstawą przygotowanego wydania stała się redakcja chronologicznie najpóźniejsza, w aparacie krytycznym oznaczona literą C. Nie tylko skreślona jest ona staranniejszym i bardziej czytelnym niż pozostałe charakterem pisma, a autor powstrzymuje się zasadniczo od nanoszenia na nią kolejnych poprawek, co nadaje jej charakter czystopisu, ale — co ważne — uwzględnione zostają w niej zmiany przewidziane na wcześniejszych etapach pracy nad tekstem. Spisana ponadto, jak podejrzewa Mirosława Hanusiewicz ${ }^{9}$, pod okiem bardziej zaznajomionego z rodzimą ortografią konfratra, odznacza się mniejszą liczbą przynajmniej niektórych wyrazistszych uchybień, tak jak w przypadku redukcji zbitki spółgłoskowej w wyrazie „królewstwo" czy palatalizacji w leksemie „rozmyszlać”. Jedynie tu także pojawiają się formy „wszystko".

W przeciwieństwie do redakcji C poprzedzające ją redakcje B i A prezentują, zaświadczony całym spektrum najróżniejszych poprawek, wytężony wysiłek autora nieustannie udoskonalającego swą translację. Dla zachowania względnej przejrzystości tam, gdzie jest to możliwe, Anonim przerabia istniejący zapis; w przypadku korekt

\footnotetext{
${ }^{7}$ G. Pozzi, Introduzione, [do:] Strage de gl' Innocenti, [w: ] G. B. Marino, Dicerie sacre e La Strage de gl' Innocenti, a cura di G. Pozzi, Torino 1960, s. 460-461; R. Rusnak, dz. cyt., s. 79-83.

${ }^{8}$ R. Rusnak, „Ale co może litość przeciw zajadtości?”. „Rzé́ niewiniątek” Giambattisty Marina w anonimowym polskim thumaczeniu, „Prace Literackie”, R. 42: 2003, s. 5-19; tenże, „Homo metaphoricus”, s. 73-89.

${ }^{9} \mathrm{M}$. Hanusiewicz, Dzieto Marino w kulturze polsko-ruskiego pogranicza. Z zagadnień jezzyka artystycznego poematu „O zabiciu Młodzianków”, [w: ] Traduzione e rielaborazione nelle letterature di Polonia Ucraina e Russia. XVI-XVII secolo, a cura di G. Brogi Bercoff, M. Di Salvo, L. Marinelli, Alessandria 1999, s. 65.
} 
bardziej radykalnych wykreśla bądź wydrapuje nieodpowiadające mu sformułowania, by poniżej, powyżej lub przy użyciu bocznych marginesów dopisać bardziej satysfakcjonujące go formy. Wpisane w niewłaściwym miejscu wersy w całości przekreśla, a następnie umieszcza je tam, gdzie znaleźć się powinny. Kolejność poszczególnych elementów zamienia przy pomocy nadpisanych oznaczeń numerycznych. Zdecydowana większość autorskich interwencji dotyczy pojedynczych wyrazów czy połączeń wyrazowych, znacznie rzadziej całych zdań. Wielokrotnie istota wprowadzanych zmian sprowadza się do kwestii odpowiedniego doboru mniej lub bardziej zbliżonych znaczeniowo leksemów, ich wzajemnego uporządkowania czy zastąpienia jednej triady rymów inną. Nie zawsze przy tym bazylianin poprzestaje na jednorazowej korekcie określonego miejsca w tekście, czasem proponowane przez niego odmiany układają się w szereg trój- i więcej elementowy. Bywa, że raz odrzucone formy wymienia na inne, ale nierzadko koniec końców wraca do swoich pierwotnych pomysłów ${ }^{10}$. Kierując się potrzebą jak najwierniejszego, a jednocześnie możliwie przejrzystego odnotowania wszystkich odmian tekstu w aparacie krytycznym ${ }^{11}$, zasadnym wydało się wyróżnienie nie trzech $(A, B, C)$, jak wynikałoby to z liczby przekazów, a pięciu redakcji utworu $\left(A_{1}, A_{2}, B_{1}, B_{2}, C\right)$, przy czym $A_{1}$ i $B_{1}$ oznaczać mają pierwotnie zapisane w przekazach $\mathrm{A}$ i $\mathrm{B}$ redakcje, $\mathrm{A}_{2}$ i $\mathrm{B}_{2}$ z kolei redakcje te po uwzględnieniu naniesionych przez autora poprawek $^{12}$.

Przyjęta za podstawę edycji redakcja C doprowadzona zostaje, a przynajmniej taką jej częścią dysponujemy, jedynie do wersu czwartego oktawy II 49, co skłania do oparcia się w stosunku do pozostałej części poematu, a są to blisko trzy czwarte całości, na chronologicznie wcześniejszej redakcji $B_{2}$. I choć ten zakładający pewną kompi-

\footnotetext{
${ }^{10}$ Poniższe przykłady uwidaczniają niektóre z tego typu translatorskich wprawek, przy czym literowe oznaczenia w nawiasach wskazują na redakcję, z jakiej dana forma pochodzi: „okrutnego” $\left(A_{1}\right)$ — „zajadłego” $\left(A_{2}\right)$ — „surowego” $\left(B_{1 / 2} C\right)$ : II 0,5 ; „rozegrzenie” $\left(A_{1}\right)$ — „rozświecenie” $\left(A_{2}\right)$ — „oświecenie” $\left(B_{1 / 2}\right)$ : II 127, 1; „onego” $\left(A_{1}\right)$ — „synaczka” $\left(A_{2}\right)$ — „onego” $\left(B_{1 / 2}\right)$ : III 22, 7; „rozdarła” $\left(A_{1}\right)$ — „przebodła” $\left(A_{2}\right)$ - „przedarła” $\left(B_{1}\right)$ — „podarła” $\left(B_{2}\right)$ : III 71, 7 .

W przypadku stosowanych tu lokalizacji cyfra rzymska odnosi się do kolejnej z czterech części utworu, następujące zaś po niej liczby arabskie to odpowiednio numer oktawy i wersu. Wobec nieznacznych różnic w objętości translacji oraz włoskiego oryginału zaznaczyć warto, iż numeracja ta dotyczy wyłącznie tekstu rodzimego.

${ }^{11}$ Dołączony do edycji poematu aparat odnotowuje wyłącznie leksykalne różnice pomiędzy poszczególnymi redakcjami, nie zaś na przykład te wynikające z odmiennego sposobu zapisu określonych wyrazów, co w przypadku autora zdradzającego za pośrednictwem stosowanej przez siebie ortografii własne przyzwyczajenia wymawianiowe odbywa się na pewno z niejakim uszczerbkiem dla pełnej wiedzy o opracowywanym przez niego utworze.

${ }^{12} \mathrm{~W}$ przypadku redakcji C, rejestrującej finalny kształt poematu i zasadniczo nie podlegającej dalszym autorskim korektom, powstrzymaliśmy się przed wyróżnianiem dwóch odrębnych redakcji, ewentualne nanoszone na nią poprawki odnotowując $w$ aparacie przy użyciu adnotacji „pierwotnie”. Podobnie postąpić trzeba było zawsze wtedy, gdy liczba proponowanych przez tłumacza odmian tekstu wykraczała poza przyjęty tu podział na pięć redakcji. Casus ten ujawnia niewątpliwą ułomność przyjętego rozwiązania, które ignoruje ponadto poruszoną uprzednio kwestię sposobu wprowadzania określonych zmian w tekście, gwarantuje ono wszakże niezbędne minimum przejrzystości aparatu krytycznego, uwydatniając to, co dla badacza filologa najistotniejsze, czyli diachronicznie ujętą ewolucję tekstu poematu.
} 
lacyjność wybór budzić może określone wątpliwości, trudno upierać się przy jakimkolwiek innym rozwiązaniu, jeśli rzeczywiście zależy nam na zgodnym z ostateczną wolą autora ustaleniu tekstu translacji. A że kwestia opowiedzenia się za tą czy inną wersją utworu ma kluczowe znaczenie dla kształtu współczesnej edycji, przekonuje już same tytuł, jaki Anonim nadaje swemu przekładowi. W redakcji $\mathrm{B}_{2}$ wyraźnie widnieje forma Opisanie zabicia niewinnych Młodzianków, która zastąpiła zapisaną uprzednio $O$ zamordowaniu Młodzianków $\left(\mathrm{B}_{1}\right)$. Nieukontentowany jednak i tym rozstrzygnięciem bazylianin wraca w wersji $\mathrm{C}$ do postaci, jaką tytuł utworu przyjął w redakcjach $\mathrm{A}_{1 / 2}$, czyli $O$ zabiciu Młodzianków ${ }^{13}$. Forma typowa przede wszystkim dla tekstów o ambicjach poznawczych, nierzadko okolicznościowych, implikująca deskryptywny, względnie zobiektywizowany charakter tekstu ${ }^{14}$ ustępuje więc miejsca konstrukcji miejscownikowej (odpowiadającej łacińskim konstrukcjom z De), w sposób całkowicie bezpośredni ewokującej temat utworu.

Ustawicznym utrapieniem naszego tłumacza, o którym z dużym prawdopodobieństwem stwierdzić można, iż polszczyznę przyswaja sobie poza rodzinnym domem, być może dopiero w klasztornych murach, okazuje się ortografia. Funkcjonując na oddalonym od cywilizacyjnych centrów swoistym "polsko-ruskim pograniczu” ${ }^{15}$ daje przystęp w sporządzonej przez siebie translacji rozmaitym rutenizmom i elementom dialektalnym ${ }^{16}$, o ujawniającej się jednocześnie jego dużej inwencji słowotwórczej nie wspominając ${ }^{17}$. Ma problemy z zaznaczaniem dźwięczności i bezdźwięczności („ogręgu — ogręku — okręgu”: I 57, 6; „głubi — głupi”: I 58, 1, I 61, 7; „słyżane” — „słyszane”: IV 57, 8), opuszcza niekiedy nagłosowe, ale i wygłosowe, spółgłoski („mutny”: I 41, 3, III 9, 6, III 29, 6, IV 27, 5, IV 61, 6; „trach”: III 36, 1, IV 23, 6, IV 50, 2; „bficie”: II 128, 3; „śmier”: IV 54, 3, IV 63, 7, IV 65, 7, IV 85, 4; „bojaź”: IV 49, 6), myli „g” z ,"” (,drujej”: I 17, 1; ,jestami”: II 20, 6), a niektóre wyrazy zapisuje, jak gdyby mazurzył (pisownia „carny”: II 139, 1; „,cerwony”: III 5, 8, III 47, 3, III 59, 8; „sarłatowy”: II 16,7). Sposobnością do licznych uchybień stają się ponadto połączenia spółgłoskowe, które częściej zdarza się Anonimowi błędnie redukować („troży”

\footnotetext{
${ }^{13}$ Spośród zajmujących się tekstem Anonima badaczy dotychczas jedynie Hanusiewicz konsekwentnie posługiwała się wskazanym tytułem i tylko ona za podstawę ewentualnego wydania uznała redakcję C poematu.

${ }^{14}$ Przykładowo wymienić można: Opisanie (krótkie) komety na horyzoncie poznańskim roku 1744 widzianego, Opisanie fortecy S. Filipa na wyspie Minorce jako prawdziwego Porto-Mahon i Opisanie festynu danego w Łazienkach rezydencyi letniej J. K. M. z okoliczności inauguracyi statui króla Jana III dnia 14 września roku 1788.

${ }^{15}$ Określenie podsunięte przez: tamże, s. 63. Przy takim usytuowaniu anonimowego autora poematu obstaje zresztą już Aleksander Brückner (dz.cyt.).

${ }^{16}$ Brückner i Hanusiewicz wyszczególniają między innymi podwajanie głoski „n” w sufiksie takich rzeczowników odczasownikowych, jak „pomieszannie”, „uważennie”, napisannie”, posługiwanie się połączeniem "tć” w leksemach typu „przybytcie”, „nabytcie”, nierozróżnianie form męsko- i niemęskoosobowych oraz specyficzną pisownię wyrazów „hidki”, ,zmyszlony” czy „monarsie” — tamże, s. 202-203; M. Hanusiewicz, $d z$. cyt., s. 66-67. Dodać można by tu pojawiające się we wcześniejszych redakcjach, rozszerzone na modłę wschodniosłowiańską formy „utraconene” (I 40, 8) i „w obarazie” (II 17, 4).

${ }^{17}$ Tamże, s. 203-204.
} 
— „trwoży”: II 67, 7; „sworzyłem” — „stworzyłem”: II 86, 1; „srzegąca” — „strzegąca”: IV 22, 2), rzadziej uzupełniać o dodatkową głoskę („wznikłne” — „wznikłe”: II $129,5)$. Nie są wyjątkiem również błędy polegające na przestawieniu sąsiadujących z sobą liter („zły” — „łzy”: III 2, 6, IV 83, 6; „szutk” — „sztuk”: III 70, 7; „w potwór” — „w powrót”: IV 45, 7) czy na podwojeniu („łuppy” — „łupy”: II 105, 3; „onna” — „ona”: III 58, 3).

Dodatkową trudność sprawiają nazwy własne, osobowe i miejscowe, zwłaszcza te z dużym prawdopodobieństwem bazyliańskiemu tłumaczowi nieznane. Nieżyjący brat Heroda raz jest „Juzyppem”, raz „Juzypem” władca Partii to „Pabp”, ale i „Patb”, a bliskowschodnia twierdza Arbela wzięta zostaje za jeszcze jednego przeciwnika króla Judei i w tekście przekładu figuruje jako „Arboł” tudzież „Arboł»”. Reguła, jakiej dopracowuje się w trzeciej dopiero redakcji, każe tłumaczowi powszechne w języku włoskim podwojenia redukować do pojedynczej spółgłoski bądź je dyssymilować, w wyniku czego ostatecznie opowiada się on za formami "Juzyp” (II 10, 4; choć nie do końca konsekwentnie), „Patb” (II 11, 6) i „Arboł” (II 11, 3). Na podobnej zasadzie bardziej znajomo brzmieć zaczynają imiona obu doradców, jacy zabierają głos w toczącej się w części drugiej poematu naradzie. „Urizeo” po pozornym zlatynizowaniu staje się najpierw „Uryzeuszem”, a potem „Uryjuszem”, „Burucco” z kolei popularnym wśród starozakonnych „Baruchem”. Egipskie „Hermopolis”, zanim zorientuje się, o jakie miasto w rzeczywistości chodzi, nazywa Anonim „Heliopolis” (II 142, 5), a określane w pierwowzorze jako „Menf” Memfis w niedużym względem siebie odstępie jest u tłumacza zarazem „Mensami” (II 138, 5), jak i „Mensyją” (II 142, 8) ${ }^{18}$.

Znaczną część pomyłek w grafii udaje się wyeliminować, i to czasem na bieżąco, $\mathrm{w}$ trakcie stopniowego cyzelowania utworu, inaczej w przypadku niemniej licznych błędów o charakterze składniowym, co oznacza, iż wiele z fraz, do których bazylianin czuje się szczególnie przywiązany, wprawia w konsternację także w ostatecznej redakcji tekstu. Sformułowania typu „z ręku robót przędzenia jest onych nabycie” (I 40, 7), „rzeka swobodzi w postrach z pomieszania” (IV 41,3), „na wzgardę swej złości zbroili żółciami” (IV 29, 8) skutecznie mącą rozumienie zdania, a współczesnego wydawcę zobowiązują do stawiania mniej lub bardziej prawdopodobnych hipotez.

Jeżeli chodzi o syntaksę omawianego poematu, to właśnie ona w największym stopniu ciąży jego poetyckiemu wyrazowi. Składnię znaczących partii tekstu cechuje sprowadzająca się często do duplikowania wyrazów synonimicznych czy też powtarzania ulubionych zwrotów-wytrychów redundancji, dotykająca nierzadko podmiotu bądź orzeczenia eliptyczność, nieprecyzyjne posługiwanie się zaimkami i spójnikami, wreszcie nagminne zastępowanie syntetycznych form przysłówków mętnymi znaczeniowo wyrażeniami przyimkowymi. W efekcie roi się w rodzimej Rzezi niewiniątek od mniej lub bardziej spektakularnych anakolutów, będących w dużej mierze konsekwencją uporczywych zmagań tłumacza ze sztywnym gorsetem oktawy, ale i trudnej do od-

\footnotetext{
${ }^{18}$ Wszystkie cytaty z włoskiej La strage de gl' innocenti pochodzą z: G. B. Marino, Dicerie sacre e La Strage de gl' Innocenti.
} 
wzorowania zwięzłości Marina, i zaledwie sporadycznie spod pióra polskiego autora wychodzą zdania, które urzec mogą swą przejrzystością i elegancją. Niewiele udaje się pod tym względem zdziałać na przestrzeni kolejnych trzech redakcji utworu, co najwyżej uzgodnić z sobą odpowiednie formy męsko- i niemęskoosobowe albo poprawić „W senie” na „we śnie” (II 132, 8), a „dla królować ani dla wojować” na „królować na ziemi ni wojować" (I 62, 1). Z jakiegoś też powodu za dużo odpowiedniejsze od zaimka względnego „który” uznaje autor konstrukcje typu „ten, co”. Konsekwentnie nanoszone korekty w tym względzie dotyczą aż piętnastu przypadków w całym poemacie.

Jeżeli w odniesieniu do sporej części poprawek o charakterze leksykalnym da się powiedzieć, iż tłumacz bierze pod uwagę alternatywy względem siebie praktycznie równorzędne i z punktu widzenia semantyki niemal całkowicie wymienialne, o tyle w przypadku innych za wiążące uznać należy kryterium stylistyczne. Nie brak przykładów poszukiwania przez bazylianina form bardziej wyszukanych, niecodziennych czy po prostu odbiegających od potoczności. Woli „wejrzeć” od „spojrzeć” (II 78, 5), „wdziewać” od „brać” (I 49, 2), a „poraźliwą” od „nieszczęśliwej” (IV 80, 4). Eliminuje odnoszące się do niewiniątek „zdychać” (III 12,8), choć w innym miejscu zamiast „wargom” pierwszeństwo przyznaje „gębie” (III 84, 3). Za nazbyt pewnie pospolite uznaje stwierdzenie ,jeszcze w się zawiera”, skoro zamienia je na „rodu nie otwiera” (III 76, 6), a czasownik „zostaje” na nieco enigmatyczne „pełnienia sporządzi” (II 23, 8). Gdzie indziej z kolei „znamienik” okazuje się stosowniejszy od „posłańca” (II 110, 1), a „niedościgłe” od „nieznajomych” (II 123, 6). Odmienną tendencję odnotowujemy w przypadku dwukrotnie użytej, i dwukrotnie nieuwzględnionej w ostatecznej wersji poematu, metaforyki odzienia. Najpierw wers „i szaty w krew szarłatną nie będą odziane” przybiera kształt: „i szaty ich nie staną krwią zafarbowane” (II 16, 4), następnie zaś „mgły piekielnej zachmurzenie” (II 63, 6) wypiera „mgły piekielnej odzienie". Komunikatywność i bezpośredniość wyrazu bierze górę nad sformułowaniami aspirującymi do poetyckości, podobnie jak niektóre z deminutiwów, ustępujące tu i ówdzie miejsca leksemom o nacechowaniu neutralnym: „syneczka” — „onego” (III 22, 7), „mleko z krwią syneczka” — „krew syna z mlekiem” (III 53, 8), „ciszkość” — „cichość” (III 88. 6).

Barokowy gust bazylianina daje o sobie znać zwłaszcza wówczas, gdy preferowanymi przez niego konstrukcjami okazują się te z silnie uwydatnioną instrumentacją zgłoskową. Do najpowszechniejszych należą nagromadzenia zmiękczeń, których prawdziwą erupcję przynosi oktawa II 80, czyniąca przedmiotem opisu świetlisty majestat Boga. Wzmianki o „ślicznym światłości aniele” (I 7, 2) i „źrzódle świętej światłości” (II $82,8)$ rozmieszczane są zatem i w innych miejscach przekładu. Szczególnie efektownie brzmią stosowane przez Anonima paronomazje, jak te pojawiające się przy okazji epizodu z pozbawioną swych młodych lwicą, co "puszcza po całej puszczy ryk z żalu surowy” (III 21,4), albo wspomnienie o utworzonych z krwi niemowląt ,szkarłatnych stawach już zastanowionych" (III 88, 5). Z drugiej strony w końcowej wersji poematu nie znalazły się takie przejawy słownej ekwilibrystyki, jak: „Zdyma, nadyma zdęte” 
wyparte przez „Sili się, ile może” (II 11, 5), „rządząc rzeczy” (II 19, 5) czy porzucone w redakcji B „Będąc kontent poniekąd, niekontent zupełnie” (IV 2, 1). Różny los staje się też udziałem co zgrabniejszych, a inspirowanych bez wątpienia Marinowym stylem, sformułowań. Odwołując się do użytego w oryginale porównania dwojga ofiar rzezi do Amora i Wenery („ed egli ed ella / Somigliavano Amore e Citerea”), stwierdza z dobitnością tłumacz: „On się w onej, ona w nim zbyt wielce kochała” (III 30, 4), tym samym unieważnia pozbawione podobnej wyrazistości wcześniejsze: „Miłość wzajemna w onych wielka przebywała". Nieco wcześniej natomiast z gwałtownej lamentacji jednej z matek znika efektowne: „Zabijasz część niewinną ciała z ciała mego”, a miejsce to zajmuje: „Zabijasz z ciała mego część w niewinnym stanie” (III 24, 5).

Mowa już była przy innej okazji ${ }^{19}$ o sporej, choć najczęściej nie idącej w parze z poetyckimi możliwościami, wrażliwości bazylianina na obficie przez neapolitańskiego mistrza serwowane „concetti”. Obecnie pozwólmy sobie przywołać scenę, w której ten sam cios dosięga zarówno matkę, jak i dwójkę jej dzieci: jedno ledwie narodzone, drugie spoczywające w jej ramionach. Marino makabreskę tę wieńczy charakterystycznym dla siebie "un colpo, un colpo sol tre vite uccide", co tłumacz oddaje początkowo w zbliżony do oryginału sposób: „w jednym razie trzy razem zabija osoby”, by w kolejnej redakcji, maksymalizując jeszcze „horrendum”, dodać — niezgodnie zresztą z sensem tego fragmentu — kolejną ofiarę i stwierdzić: „wraz cztyry jednym razem zabija osoby” (IV 14, 8).

Rozważając natomiast stosunkowo najistotniejsze dla nas poprawki o charakterze ściśle już semantycznym, zaznaczyć trzeba, iż wyraźnie częściej zdarza się Anonimowi w dopracowywaniu własnego tekstu oddalać od literalnego sensu pierwowzoru aniżeli do niego się przybliżać. Według orientacyjnych szacunków w tym zakresie drugi ze wskazanych tu modelów postępowania odnotowujemy średnio dwa i pół raza rzadziej w porównaniu z pierwszym. Bezsprzecznie świadczyć musi to o wzrastającym z czasem u bazylianina poczuciu własnej swobody twórczej, na której rzecz stopniowo przełamuje początkowe dążenie do względnie pełnej zgodności z włoskim oryginałem. Niekiedy zasadniczo liberalizujące się podejście tłumacza do tekstu wyjściowego zdradzać zaczyna ukryty zamiar jego poprawiania, co w stopniu szczególnym odnosi się do precyzyjności używanych przez Marina stwierdzeń.

Przykłady można by mnożyć, ograniczmy się więc do wspomnienia „admirabil fanciul' z przestrogi Juzypa, który po początkowym zamyśle spolszczenia go w zbliżony do pierwowzoru sposób („dziwne dziecię”) przekształca się ostatecznie w „dziwnego synka” (I 51, 3), co stanowi już całkiem bezpośrednią peryfrazę małego Chrystusa. Albo „chytrości” (IV 49, 3), którą to cechę uznaje tłumacz za lepiej charakteryzującą Malecha w momencie, gdy przystępuje on do okrutnego droczenia się z mamką Albiną, od wskazanej przez Włocha fierezzy.

$\mathrm{Na}$ docenienie z pewnością zasługują te z translatorskich koniektur, które nazwać można by tyleż znaczącymi, co subtelnymi. Bliższe Marinowemu che giova jest oczy-

${ }^{19}$ R. Rusnak, „Homo metaphoricus”, s. 84-89. 
wiście pojawiające się w redakcji $\mathrm{A}_{1}$ „pomaga”, ale wziąwszy pod uwagę, iż przemawiający w tym fragmencie Uriusz odnosi się do przyszłości, bardziej uzasadnione wydaje się użycie wybranej ostatecznie przez Anonima formy „pomoże” (II 24, 1). Podobnie rzecz się ma $\mathrm{z}$ „Fu punito l' error pria che commesso”. Właściwsza od formy czasu przeszłego dla oddania uniwersalnego charakteru więzi, jaka w planie moralnym spaja winę z karą, wydaje się rzeczywiście konstrukcja z użyciem „praesentis”: „Jest błąd, nim popełniłeś, sam w sobie skarany" (IV 81, 8). To samo da się powiedzieć o roztropnym zastąpieniu anaforycznego qui z oktawy II 107 rodzimym zaimkiem „stąd”, tym adekwatniejszym, iż mowa o mających swe źródło w czole alegorycznej Wizji objawieniach.

Ta sama zasada przydawania używanym sformułowaniom odpowiedniej dozy precyzyjności przesądza też o nierzadkim wcale zwyczaju przywracania leksemów zgodniejszych z oryginałem, a wcześniej rozmyślnie zarzuconych. I tak, gdy wspominając Boży akt stworzenia świata włoski autor jasno przypisuje konkretnym kategoriom zwierząt określone sposoby poruszania się („lo striscio a gli angui, a le fere il corso"), tłumacz, mimo iż na początku chód kojarzy ze zwierzętami, a z bydłem biegi, w kolejnej redakcji decyduje się na bardziej chyba uzasadnione rozwiązanie: „zwierzętom biegi” (II 87, 5), „bydlętom chody” (II 87, 6). W nieco innym miejscu „Giustizia e Pietä" przekładać próbuje jako „Łaskawość, Sprawiedliwość”, do momentu jednak, gdy — jak należy przypuszczać — uświadamia sobie, iż Pietà, do której swego władcę nawołuje Uriusz, tożsama może być z pojawiającą się krótko potem spersonifikowaną Litością (II 46, 7).

Do podobnej grupy przypadków zaliczyć wypada sytuacje, w których wraca Anonim do użytych przez Marina nazw własnych. Nie doczekują tego wszystkie z występujących w Strage "nomina propria”, a jak wiadomo, z najbardziej erudycyjnymi passusami potrafi się bazylianin obejść dość radykalnie (przypadek piekielnych biesiadników z części pierwszej). Tym niemniej na dalszych etapach opracowywania przekładu pojawiają się na nowo i „Fary” (II 125, 1) — tak nazywa Anonim słynną aleksandryjską latarnię — i „sfingi” (II 125, 3), i „Samaryja” (IV 43, 1), w której toczy się akcja przywołanej w pewnym momencie opowieści z II Księgi Królewskiej. Dostaje się też na karty polskiego tłumaczenia niezwykle istotny dla poematu Cavalier d' Arpino, którego miano pojawia się w anonsującym morderstwo pięciu braci pytaniu: „Kto kiedy widział ręką sławnego Arpina / odmalowaną litość w sztuce doskonałą?” (III 57, 1-2). Uprzednio wystarczała autorowi zwykła wzmianka o "malarzu”, a jeszcze wcześniej (efekt faktycznej niewiedzy, o kim właściwie mowa) o „wynalazcy”.

W swym dążeniu do konkretu nie unika tłumacz również odniesień stricte fizykalnych, z których swoją drogą trudno byłoby całkowicie zrezygnować w przypadku tekstu tak intensywnie epatującego grozą śmierci. W przypadku „pępka” (III 13, 8), który u Anonima zastępuje eufemistyczne il nodo, jest to kwestia indywidualnej inwencji autora, gdzie indziej zwrot ku nieco drastycznym stwierdzeniom oznacza opowiedzenie się za propozycjami samego Marina. Włoskiemu „vede di brutte macchie altri coverti” ma pierwotnie odpowiadać wyzbyte podobnej sugestywności „widzi tam 
wielu jeszcze ducha oddających”, by w rezultacie przyjąć postać następującą: „Widzi niektórych szpetne zmazy w się mających” (III 83, 1). Dość analogicznie "ov’ egli il fiede e batte”, mające najpierw brzmieć jako „srodze, bez litości”, staje się w efekcie dosadnym „wtapia, przebija i żyły” (IV 13, 3) ${ }^{20}$.

Inna część korekt z kolei motywowana wydaje się być względami przede wszystkim wyznaniowymi, tym bardziej, że w dostatecznym już stopniu poświadczone zostało przywiązanie anonimowego bazylianina do chrześcijańskiej wizji świata ${ }^{21}$. Do takich zmian należy niewątpliwie uczynienie elementami skazanego na wytracenie pogaństwa zborów i meczetów (I 13, 5) w miejsce pojawiających się uprzednio zborów i kościołów, czy zastąpienie skierowanego do Szatana zwrotu „najwyższy panie” budzącym mniejsze zastrzeżenia „przezacny panie” (I 30, 7). Uwagę przykuwa także fragment z monologu samego Boga, w którym objaśnia On założenia zbawczej misji Chrystusa. Choć początkowo trud odkupienia ludzkości określony zostaje w przekładzie jako „zlecony tu Mu w wysokości” (zgodnie zresztą z włoskim pierwowzorem: „Che commessa da me gli fu qua sopra"), w późniejszej redakcji autor uznaje woluntarystyczną, rzec można, autonomiczną akceptację Syna Bożego dla czekających go wyrzeczeń, dlatego czytamy: „tu w niebie z swojej woli na siebie przyjętej” (II 89, 8).

Mamy wreszcie przypadki eliminowania dość oczywistych i często niezgodnych z oryginałem semantycznych wpadek, jakie przytrafiają się bazyliańskiemu translatorowi w trakcie jego niełatwej pracy; jak wtedy, gdy ruszających na krwawe żniwo żołnierzy nazywa, miast „uzbrojonymi” (IV 5, 2), „uzdobionymi”, albo gdy w ewidentnej opozycji do lata stawia nie zimę (II 79, 5), lecz ziemię. Aż dwa interesujące przykłady dotyczą noszonych przez bohaterów Rzezi bród. Początkowo proponuje Anonim, by Malech „poprawiał swojej brody włosy”, by ostatecznie wpisać: „na swej głowie włosy” (IV 34, 7). Co do brody zaś Uriusza nie od razu wydaje się przekonany, że ma mu ona zakrywać piersi (II 19, 8), a nie oczy.

Obok egzemplifikowanej dotychczas nazewniczej ścisłości, ku której przesuwa swoją translację anonimowy rymotwórca, inną istotną dominantą podejmowanych przez niego zabiegów wydają się być kwestie poetyckiej ekspresji. Czasem chodzi o przydanie dodatkowych rumieńców wizerunkowi dręczonego Szatana, który w efekcie „ryczy” (I 5, 5) i „woła” (I 23, 1; wcześniej odpowiednio „krzyczy” i „mówi”), czasem o bardziej zdecydowane potępienie władzy tyrana (,jest Bogu, niebu, ziemi niepodobająca”: II 24, 8; wcześniej: „nie podoba się Bogu, grzech w sobie mająca”), czasem wreszcie o hiperbolizację poniesionej przez Heroda straty („Biada mnie”: IV 84, 8 — „Dlaczego”; ,jęcząc nad tą męką”: IV 89, 7 — „dopuścić się tego”). Znacznie czę-

\footnotetext{
${ }^{20}$ Zdecydowanie mniej sytuacji, w których leksem, bądź całe sformułowanie, o znaczeniu szerszym zastępuje to pod względem semantycznym ściślejsze. I tak na przykład zamiast „maluczkie Żydowie” czytamy „maluczkie synowie” (II 78, 3), zamiast o „pałacu królewskim” wspomina się o „królewskim mieszkaniu” (IV 41, 1), a z wersji finalnej poematu znika informacja o wyciąganiu puginału „z pochw” (w ich zastępstwie pojawia się określenie „wtym”: IV 79, 5) czy o spinającej suknię Wizji „klotce pod goleniem” (II 96, 6), a w miejsce całkiem sugestywnego „Ta za ręce, ten trzyma za nogi”, opowiada się Anonim za frazą: „Ten targa zapalczywie, ta broni daremnie” (III 23, 4).

${ }^{21} \mathrm{R}$. Rusnak, „Ale co może litośc”, s. 15-17.
} 
ściej jednak rzecz dotyczy z jednej strony srożących się nad betlejemską dziatwą prześladowców, z drugiej oddanych w ich wszechmoc Młodzianków i współcierpiących z synami matek. Diachroniczny ogląd wszystkich dochowanych redakcji potwierdzałby zatem wnioski płynące z całościowej analizy porównawczej translacji z włoskim poematem: anonimowemu autorowi, mającemu na uwadze względy dydaktyczne, zależy na możliwie dobitnym uwydatnieniu zarysowanej pomiędzy katem i ofiarą opozycji.

Demonstrując barbarzyńską naturę oprawców, w tym samego Heroda, posługuje się bazylianin odpowiednio jednoznaczną nomenklaturą. O bezimiennym siepaczu z części trzeciej mówi się, iż był „w zabójstwo udany” (III, 46, 7; zamiast wcześniejszego „na rozbój udany”), a we łbie była mu „morderstwa rana zadana” (III 47, 4; wcześniej po prostu „ta rana”). Podekscytowany sennym widziadłem władca burzy „ni szalony” (II 7 , 4), a gdy dosięga go ręka sprawiedliwości, woła w swoim kierunku: „O, jak srodze okrutny” (IV 86, 1). Na gwałtowności i zdecydowaniu przybierają też z redakcji na redakcję przypisane zabójcom ruchy. „Prędko się rzucił hetman” (IV 64, 2): czytamy o Malechu, najokrutniejszym z pomagierów Heroda. W pierwotnej wersji miast rzucać się, jedynie rusza. Podobnie gdzie indziej „nadbiega” (III 54, 1) zastępuje wcześniejsze „nadchodzi”, a to z kolei zajmuje miejsce formy „przybywa”. „Odchodzi” wyparte zostaje przez „porzuca” (IV 17, 1), a „krok obraca” przez „bieg obraca” (III 60, 1) 22. $^{22}$.

Przeciwstawną tendencję obserwujemy biorąc pod uwagę krwawo unicestwiane niemowlęta i ich matki. W ich wypadku Anonim stawia na wywoływanie wrażenia czułości, bezbronności i niewypowiedzianego bólu. Dlatego jeszcze zdecydowaniej niż w początkowych wersjach tekstu mówi się o przedśmiertnym „drganiu” (IV 63, 7), „ostatnim jęczeniu” (IV 21, 1), tonięciu we własnej krwi (IV 37, 6) czy „zdręczonych ostatkach” (III 72, 8). Jeśli zaś chodzi o liczbowe oddanie skali zadanych cierpień, to w miejsce włoskiego ,cento e cento punte a morte” umieszcza autor hojne „sto setnemi ranami”, by zastąpić je następnie „tylo” i ostatecznie poprzestać na liczbie „tysiąc” (IV 61, 4).

$\mathrm{Z}$ niemniejszą atencją traktowane są i betlejemskie matki. Do ich rozpaczliwego repertuaru należą „łzy krwawe” (III 85, 1; III 87, 5), „żałobliwe jęczenia i ryki” (IV 8, 8), „lednienie wnętrzności” (IV 25, 2) i „oczu zawieranie” (III 76, 2). Za każdym razem sformułowania o większej sile ewokowania zastępują te bardziej wyważone ${ }^{23}$. Częściej jednakże niż w wypadku ich małoletnich dzieci decyduje się Anonim także na zmiany uwidocznioną ekspresywność osłabiające. Usuwa na przykład z redakcjach $\mathrm{B}_{1 / 2}$ wzmiankę o drżeniu Albiny w chwili, gdy miota ona gniewne oskarżenia względem zabójców swego syna (IV 62, 5). Na karcie $110 \mathrm{v}$ rękopisu natomiast rozszyfrowujemy

\footnotetext{
22 Odnotować wypada wszakże również przypadki wskazujące na postępowanie zgoła odmienne. Oto odsądzany od wszelkiej czci Malech z „najniecnotliwszego” staje się „niecnotą zawzięcia” (IV 3, 1), a zły doradca Baruch z „niecnotliwszego nad królewskie złości” jedynie „frantowniejszym nad króla obroty” (II 39, 3). Nie wspomina się także w późniejszych wersjach przekładu o „okrutności” Heroda (II 111, 8) ani o jego „zawzięciu” (II 61, 3), a zamiast w chwili gwałtownego wzburzenia wyrywać sobie włosy z głowy, srogi władca zaledwie je targa (II 7, 6).

${ }^{23}$ Znaczące choćby to, że tłumacz wykreśla jedyną uczynioną przez siebie wzmiankę o współuczestniczących w boleści ojcach: „Męże nad żonmi, dziećmi żalą się smutnie” (IV 0, 3). W wersji końcowej żal nad uśmiercanymi przypisany zostaje wyłącznie matkom.
} 
spod dokonanych skreśleń, iż w miejsce słów: „Którego z was mam płakać, niewiasta żałobna, / nie wiem sama” (III 74, 3-4) znaleźć się miały jeszcze bardziej wymowne: „Zgaszona moja światłość ciemności żałobna, / chmurzy w oczach łez powódź”.

Zdawkowo przywołane tu najbardziej charakterystyczne ze zmian, jakim poddaje tworzony przez siebie tekst anonimowy tłumacz, potwierdzają — jak mniemamy — zasadność ujęcia diachronicznego, uwzględniającego powstałe w różnym czasie wersje tego samego utworu. Poza wszelkimi wątpliwościami wydaje się fakt, iż dzięki takiemu założeniu badawczemu tekst zaczyna przemawiać pełniejszym niejako głosem i odsłaniać skryte pod wierzchnią warstwą pokłady. Warto przy okazji skonstatować, iż na tak pogłębione studia z pewnością zasługują także teksty mniej znane, nie zawsze najwyższych lotów, ważne jednak dla pełniejszej wiedzy o naszej kulturze w dawnych wiekach.

\section{Notes in the Margin of Edition of a Basilian Poem The Massacre of the Innocents}

\section{Summary}

This paper is intended to gather some remarks regarding a first published late-Baroque poem The Massacre of the Innocents, being an anonymous Polish translation of Giambattista Marino's work. After giving a sketchy characterization of the poem and displaying the main reasons of its publication, the author proceeds to conclusions drawn from the simultaneous reading of three existing versions of the Polish text survived in one of the Ossolineum manuscripts. He dwells on the paths the translator takes arduously forming and transforming his version of the Italian poem, pointing out the main types of corrections he makes and trying to present a reasonable explanation for his artistic choices. The paper intends though to shape a more profound picture of the work taking into account not only the final (or the one considered to be such) form of the text but also all the traces of the translator's continuous labour conserved in the extant versions of the Polish poem. 